\title{
Countertrade Mechanism of Global Arms Trade: Case Study of Indonesia
}

\author{
Zainal Arifin ${ }^{1}$, Agus $\operatorname{Suman}^{1} \&$ Moh. Khusaini ${ }^{1}$ \\ ${ }^{1}$ Faculty of Economics and Business, Universitas Brawijaya, Malang, Indonesia \\ Correspondence: Zainal Arifin, Faculty of Economics and Business, Universitas Brawijaya, Malang 65300, \\ Indonesia.
}

Received: August 29, 2019

Accepted: October 7, $2019 \quad$ Online Published: November 22, 2019

doi:10.5430/ijfr.v11n1p307

URL: https://doi.org/10.5430/ijfr.v11n1p307

\begin{abstract}
A strong national defense system serve to maintain the nation's honor such as creating peace, security, and sovereignty and becomes an effective instrument for bargaining position in relations between nations so that it has broad impacts, including impacts on economic aspects. The research approach used is a qualitative approach. This type of research is a systematic review research. Likewise, the defense industry of a country reflects the economic strength of its country, because in carrying out the defense function, the defense industry has a very important role, including in holding the national Main Tool of the Armament System. However, now not all defense equipment can be produced by the domestic defense industry, so some defense equipment must still be held in cooperation with foreign countries. Law No. 16 of 2012 concerning the Defense Industry mandates that procurement of defense equipment from abroad be permitted if it fulfills several requirements, including trade returns, local content, and offset. Counter trade is one of the mechanisms of cooperation that has been carried out by Indonesia. This mechanism allows reciprocal trade between two countries by buying goods from abroad with payment in the form of goods worth the goods imported. So it is important to analyze the potential for economic improvement for Indonesia that is generated by the mechanism of trade defense equipment from abroad, so that in conducting cooperation, Indonesia can benefit both in the short and long term.
\end{abstract}

Keywords: trade, defense equipment, foreign cooperation, exports, superior commodities

\section{Introduction}

National defense is all efforts to maintain the country's sovereignty, the territorial integrity of the nation and the safety of the whole nation from threats and disturbances to the integrity of the nation and state (Elden, 2006). The nature of national defense is any universal defense effort whose implementation is based on an awareness of the rights and obligations of citizens and a belief in one's own strength. Law Number 3 of 2002 concerning National Defense has mandated that all national resources in the form of human resources, natural resources and artificial resources, values, technology, and funds that can be utilized to enhance the capability of the national defense which are further regulated by article 20 paragraph 2 of Government Regulation (Sebastian \& Gindarsah, 2013; Gindarsah, 2016). The geographical condition of Indonesia, as an archipelagic country, requires a defense system capable of realizing and defending the entire territory of the Republic of Indonesia as a defense unit to protect and protect from all forms of threats (Arif \& Kurniawan, 2018). For developing countries, the defense and security system requires the availability of key equipment that is supported by the ability of the domestic industry, ownership of advanced technology and appropriate technology, control of economic resources, as well as accelerating the achievement of national goals (Bitzinger, 2009; Goldstein, 2002; Ocampo, 2018) . During this time, the availability of Indonesia's defense and security equipment has not been supported by the ability of the defense industry optimally and independently so that there is still dependence on defense and security equipment products from abroad (Basar \& bt Zulkifli, 2019; Laksmana \& Mattis, 2018, Rahman, et al., 2018). A strong national defense system is not only able to maintain the nation's honor, but also becomes an effective instrument for bargaining position in relations between nations. To realize these conditions in addition to the demands for the availability of professional soldiers, we also need the support of equipment and means of defense that can be relied on in line with technological developments and the estimated level of threats faced (Gunawan, 2017; Till, 2015). This was said by President Susilo Bambang Yudhoyono after reviewing the navy's main weaponry system, the Koarmatim Ujung Surabaya in East Java 
(Boediwardhana, 2014).

According to Karim (2014), a defense industry owned by a country also reflects a country's economic strength. Likewise, national economic development and national defense are interconnected with one another (Chowdhury, 1991; Joerding, 1986; Deger, 1986). National economic development aims to create economic opportunities and improve the welfare of the community, while national defense is held to answer all forms of threats that come from inside and outside. The role of the defense industry is urgent for a country because it provides a deterrence effect to other countries (Snyder, 2015; Bunn, 2007; Weida \& Gertcher, 2019), while providing a multiplier effect or a multiplier effect both in economic and technological terms for nation. However, arms trade on a global scale provides several competitive exceptions for some parties, especially major arms manufacturers. Countries with high-tech weapons production capabilities have a competitive advantage compared to their buying partners (for more discussion, Bitzinger, 1994). Purchaser countries will usually require substantial funding from the state budget to finance these military needs. On the other hand, the process of technology transfer is proceeding with difficulty, so that the advantage remains in the hands of the producers, and does not allow the transfer of the ability to produce weapons and other military equipment (see for instance, Brauer \& Dunne, 2011; Markusen, 2004). In some cases, buyer countries need to buy them with commodities to obtain this strategic weapon, such as in the case of Sukhoi purchases between Indonesia and Russia in 2007 (Rangsimaporn, 2009; Dikici, 2015; Puspita, 2018). In such a context, it is known that arms trade on a global scale creates an imbalance in position and a lack of value and financial opportunity that a purchaser country might obtain with an existing trade scheme. For this reason, this paper seeks to observe and determine the schemes that might be obtained by weapons-buying countries to obtain trade return, by taking a case study in Indonesia, by using the countertrade approach, where the exchange of goods can be more utilized compared to the purchase of weapons through money. Some major export commodities, in this context, which are owned by Indonesia, can be used as the basis for creating a new scheme in the acquisition of non-financial returns for arms-buying countries.

\section{Literature Review}

\subsection{Weapon Procurement and Trading Imbalance: Case Study of Indonesia}

The defense industry produces the main defense system which will be utilized by the state military forces (TNI) in efforts to defend the country. In accordance with Regulation of the Minister of Defense of the Republic of Indonesia Number 17 of 2014, procurement of defense equipment includes domestic defense equipment obtained from domestic industries both SOEs and BUMS, as well as foreign defense equipment. At present, the condition of the domestic defense industry is at an intermediate technological level (Sjamsoeddin, 2016). This means that products from the national defense industry have been produced and used by the TNI. For example, land defense equipment made by PT. Pindad ranging from pistols and assault weapons to mortars and tire wheel combat vehicles (Panzer Anoa) which have supported the needs of the Army. In fact, PT Pindad's products are now UN-standardized. Weapons of Pindad Products used by the Army have 11 times won the overall championship at the Australian Army of Skill Arms at Meeting (AASAM) shooting tournament. Procurement of domestic defense equipment creates opportunities for job creation and saves foreign exchange. Some examples of domestic companies include PT. Pindad which produces a rocket launch vehicle, PT. Dirgantara Indonesia which produces CN-295 aircraft, PT. PAL which produces warships, and others.

Nevertheless, not all defense equipment needed can be produced by the domestic industry, so it needs to be imported from abroad. For example Leopard Tank 2 made in West Germany, Scorpion Tank made in England, F2000 Corvette Ship made in England and Sigma Corvette made in the Netherlands, Sukhoi F-35 made in Russia and others. As in article 43 of Law 16 of 2012, Defense and Security Equipment Tools can be procured from abroad if they meet the requirements: Defense and Security Equipment Tools have not or cannot be made domestically; include Defense Industry participation; technology transfer obligations; guarantee of no potential embargo, political conditionality and barriers to the use of defense and security equipment tools; trade returns, local content and/or offset of at least $85 \%$; local content and/or offset as low as $35 \%$ with an increase of $10 \%$ every five years. Counter trade scheme is one of the potential defense equipment procurement schemes from abroad for Indonesia because it produces various economic opportunities. can generally be described as a form of trade involving the exchange of goods or services, between seller and buyer, which is paid for, using, in whole or in part, with other goods or services. In Indonesia, the provisions on trade returns have been regulated in the Republic of Indonesia Government Regulation No. 29 of 2017 Regarding the Payment of Goods and How to Deliver Goods in Export and Import Activities and Regulation of the Minister of Trade of the Republic of Indonesia Number 28/M-Dag/Per/5/2017 Concerning Changes With regard to Regulation of the Minister of Trade No. 44/M-Dag/6/2016 concerning Provisions for Purchase Returns for 
Procurement of Imported Government Goods. In this regulation it is stated that the payment of Goods in Import activities can use payment methods of Trade Returns or payment methods of Goods in other forms. Payment methods for Trade Returns can be in the form of barter, buyback, buyback, and offset.

Specific to the trade of defense equipment, the mechanism has been regulated in the Republic of Indonesia Government Regulation Number 76 of 2014 concerning the mechanism of Trade Return in the Procurement of Foreign Defense and Security Equipment Tools and the Minister of Defense Regulation of the Republic of Indonesia No. 30 of 2015 concerning Trade Returns, Local Content, And Offset in the Procurement of Defense and Security Equipment Tools from Overseas, which in both of which is referred to as Trade Returns is a reciprocal trade activity between Indonesia and foreign parties as measured in the contract value of the procurement contract for defense and security equipment tools.

Despite having great economic opportunities, the implementation of trade returns in Indonesia has not yet reached maximum results. One example is the purchase of the Sukhoi SU-35 aircraft from Russia. The purchase value of SU-35, which reached USD 1.14 billion, provides export potential to Russia for Indonesia by $50 \%$ of the value of the purchase, or worth USD 570 million. In the MoU it was agreed to purchase more than one export commodity, with choices in the form of processed rubber and its derivatives, CPO and its derivatives, machines, coffee and its derivatives, cocoa and its derivatives, textiles, tea, footwear, processed fish, furniture, copra, plastic and its derivatives, resins, paper, spices, defense industry products, and other products. With this purchase return, Indonesia has the opportunity to export commodities that have already been exported as well as those that have not been previously exported. Nonetheless, in the process, the practice of trade returns also encountered obstacles, for example in the selection of commodities exchanged with Sukhoi. Not all commodities offered will be accepted by Russia just like that, considering that they also consider the added value of these commodities. For example, the Indonesian government wants trade returns to include 20 commodities. Russia however only wants 10 commodities. The amount is smaller than that offered, because there are certain commodities that can be produced by Russia alone. The discussion of commodities to be bartered with Russia was conducted jointly between the Ministry of Defense and its apparatus and the Ministry of Trade and its instruments including the PPI. Previously, there were also a number of changes to Indonesia's barter agreement with Russia. The Russian government had previously wanted to buy raw rubber, but Indonesia wanted the trade of rubber in the form of finished goods namely tires to improve the domestic industry. In addition, obstacles also occurred in the signing of the main contract between Indonesia and Russia which waited quite a long time. The main contract of trade agreement between Indonesia and Russia was signed on February 14, 2018, but it has not been determined exactly which commodities will be traded. While the commodities most likely to be chosen by Russia are rubber and CPO. Until the 4th quarter of 2018, the cooperation contract in the activation process at the Ministry of Finance was related to a loan agreement. The new trade return will run if the contract has been declared effective, marked by the opening of a letter of credit by the Ministry of Finance and continued payment of advances to Russia.

Completion of the contract signing will greatly help the Ministry of Trade to maintain the balance of trade balance at a macro level, because it means that trade with Russia can begin. With the interrelated roles of each other between the Ministry of Defense and the Ministry of Trade, coordination and cooperation between the two ministries must be well established to accelerate the realization of trade returns with Russia. Conversely, if trade-off cooperation does not materialize, economic potential can be obtained instead. With this background, this paper wants to explain the economic opportunities of trade returns by analyzing the current position of Indonesia's defense and mapping of Indonesia's leading commodities that are likely to be exchanged in trade returns.

\subsection{Counter Trade}

Each country must have a specific reason to encourage counter trade. Two main reasons, according to Reisman et al. (1988), are to safeguard currencies and improve the trade balance. Countertrade is a form of international business behavior in which import transactions are related to reciprocal export transactions (Zurawski and Swechmezan in Fletcher, 1996). Hennart and Anderson (1993) have defined countertrade transactions as transactions in which the seller provides the goods to the buyer and contractually agrees to buy goods from the buyer that are equal to an agreed percentage of the initial sales contract value. A distinguishing characteristic of other trades is that trade returns have a form of barter-type transactions. There are at least three things that affect the flow of trade that is related to (i) the nature of traded goods, (ii) the extent to which trade flows offset each other and (iii) the length of time needed to complete both transactions.

There are a number of forms including barter, counter purchase, offset and buy-back. Countertrade is different from other forms of international business behavior because long periods of time are needed in negotiations (large 
transaction value and number of parties involved), more complex (many things required in transactions) and government involvement (Fletcher, 1996).

Trade return is a form of procurement mechanism for foreign defense and security equipment in addition to local content and offsets. The form of procurement from abroad is not merely the purchase of defense and security equipment, but also in the form of repairs and maintenance because in the country its ability is still limited in carrying out repairs and maintenance on its own. Trade returns in the procurement of foreign defense and security equipment are made through barter or counter purchase. Calculation of trade return, local content, and offset (IDKLO) is not less than $85 \%$, while the local content and offset are not less than $35 \%$. The illustration and formulation of the calculation are as follows:

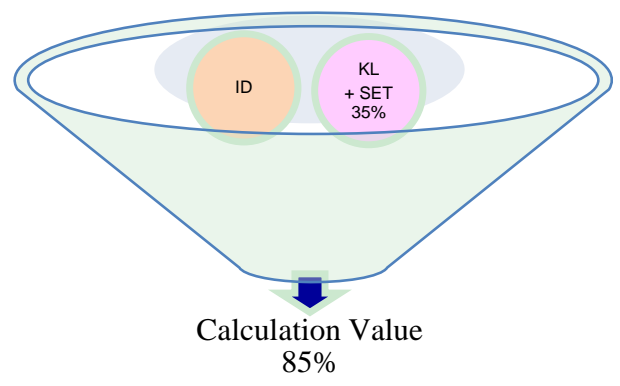

Figure 1. Calculation of trade returns calculation value

$$
\begin{aligned}
& \mathrm{ID}=\sum \text { BKID } i \times \mathrm{HIKID} i \\
& \mathrm{KL}=\sum \text { BKKL } i \times \text { HIKKL } i \\
& \mathrm{SET}=\sum \text { BKSET } i \times \text { HIKSET } i
\end{aligned}
$$

In which: ID= Trade Returns; KL=Local Content; $\mathrm{SET}=$ Offset; $\mathrm{BKID}=$ Trade Return Component Weight; HIKI = Price of Trade Return Component Items; BKKL= Weight of Local Content Components; HIKKL= Price of Local Content Component Items; BKSET= Offset Component Weight; HIKSET=Offset Item Price

Regarding the position of trade returns in international trade, offset has two different types according to its relationship with the imported weapons system: direct and indirect. Direct offset is related to weapons systems or related services that are exported by defense companies and usually includes technology transfer, buybacks, overseas training, technical assistance, joint production/co-production, acquisition care ability, and others. Indirect offset is an offset that is not related to the weapon system or related services of foreign defense companies. These include the purchase of defense equipment, training, technology transfer, technical assistance and trade rewards. Therefore, according to Jang et al (2007), trade returns are part of offset.

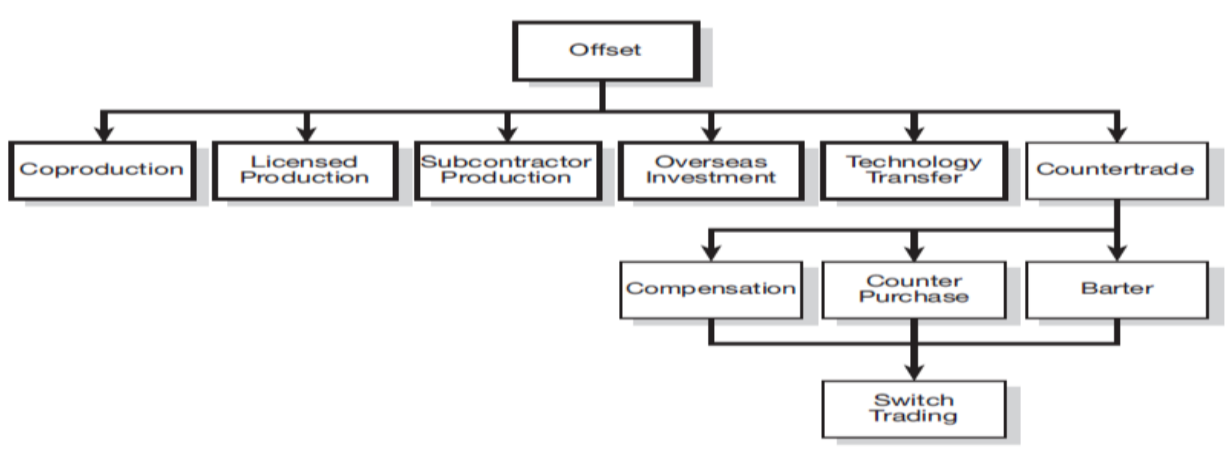

Figure 2. Position of trade returns in international trade

Source: Jang et al (2007) 
Furthermore, trade returns or countertrade which is part of offset can be carried out through three mechanisms, namely compensation, counter purchase and barter. These three mechanisms can be classified into switch trading because trading is two-way.

\section{Results}

\subsection{Indonesia's Current Defense Position}

As stated by Sjamsoeddin (2016), the ability of the domestic industry is now at an intermediate technology level and has the potential to be developed. However, since the abolition of the strategic industry concept, SOE defense companies such as PT Pindad, PT DI, PT PAL, PT Krakatau Steel, and others are now required to be able to carry out business as usual principles including efficient, economical, etc. (Tuwanto, 2015). Large incentives that were given in the past were drastically removed and had to compete normally. This principle is often not in line with the nature of the defense industry itself. Consumers of the defense industry are monopsony (TNI) so the market for defense industry products is limited. If you want to spread your wings to foreign markets, you may not be able to compete (due to efficiency factors) and may not necessarily get government approval (avoiding the possibility of domestic-made weapons being bought by countries that are likely to fight Indonesia). Meanwhile, domestic defense companies often find it difficult to develop investments and conduct research because of the lack of funding and limited incentives from the government.

However, the national defense industry continues to make improvements. In 2010 a national defense industry policy body was formed called the Defense Industry Policy Committee (KKIP). KKIP's task is to develop the capabilities of the domestic defense industry, both defense equipment and non-defense equipment. In its development, for example, land defense equipment made by PT. Pindad ranging from pistols and assault weapons to mortars and tire wheel combat vehicles (Panzer Anoa) has supported the needs of the Army. In fact, PT Pindad's products are now UN-standardized, as well as its tactical surveillance vehicles. For air defense equipment, PT Dirgantara Indonesia is developing a production collaboration with Airbus Military to build a medium transport aircraft CN 295 with the aim of increasing the ability to produce light transport aircraft, such as C-212, CN 235, and CN 295, which has 50 parachutes. In addition, on the side of the marine defense system, we even have several reliable domestic defense industries. PT PAL is relied upon for the manufacture of large-scale warships, such as class corvettes and submarines. PT PAL was also encouraged to build warships for tankers (Sjamsoeddin, 2016).

Global Firepower (2019) which released the results of its latest survey of countries with the strongest military in the world. To assess a country's military strength this survey uses 55 individual parameters. Thus, a small country with a military that is not too big but has qualified technology can be ranked at the top. The survey also did not include a stockpile of nuclear weapons even though countries that are believed to have nuclear power have their own judgment. For this year, Global Firepower examined 137 countries including several new countries that were not included in the assessment last year, namely, Ireland, Montenegro and Liberia. The list of countries with the strongest military is indeed not much shifted. In the top three are still occupied by the United States, Russia and China, while Indonesia ranks 15th in the world with an index of 0.2804. Indonesia is also the strongest country in Southeast Asia. In this case it is shown that Indonesia ranks top in national defense/military capability. At present, Indonesia in the Global Firepower notes released by SIPRI (2019) has active military and reserve personnel reinforced with tanks, which rank 52 out of 137 countries, subsequently armored vehicles ranked 47, artillery ranked 30, and rocket launchers occupy ranked 47th. In addition, Indonesia has aircraft including fighter jets and helicopters ranked 30 out of 137 countries. While Indonesia's maritime strength is quite strong, because it is supported by warships consisting of frigates, corvettes, submarines, patrol boats, and minesweepers.

The national defense policy is implemented to manage all national infrastructure resources and facilities in order to achieve the national defense objectives in the framework of supporting national development. National defense development refers to a management system that is implemented comprehensively, so a policy is needed on various related aspects. So to increase the capacity of the domestic defense industry, one of the directions for national defense policy is to strengthen cooperation with friendly countries in the framework of capacity building (Indonesian Ministry of Defense, 2018). Regarding cooperation with foreign countries, as in article 21 of Law No. 16 of 2012 concerning the Defense Industry, that coordinating foreign cooperation in order to advance and develop the Industry is included in the duties and authority of KKIP. One form of cooperation with other countries in the form of trade cooperation.

\subsection{Financial Values in Trade Returns for the National Economy}

Through the trade return mechanism, various economic opportunities can be obtained by Indonesia, mainly through 
export potential that generates foreign exchange. According to the nature of two-way trade return transactions, Indonesia needs to prepare any commodity that has the potential to be exchanged for trade returns. According to the Ministry of Trade's Foreign Trade Export Bulletin, Indonesia annually exports at least 92 types of commodities. Of all the commodities, based on the average export value each year, the Ministry of Trade groups a number of commodities into 10 Major Commodities and Potential Export Commodities (Indonesian Ministry of Trade, 2017). The main commodities are the commodities that are ranked top with the highest export value, while potential commodities are commodities that have high export values and have the potential to be continuously improved. Data for each commodity group is as seen in Figure 3.

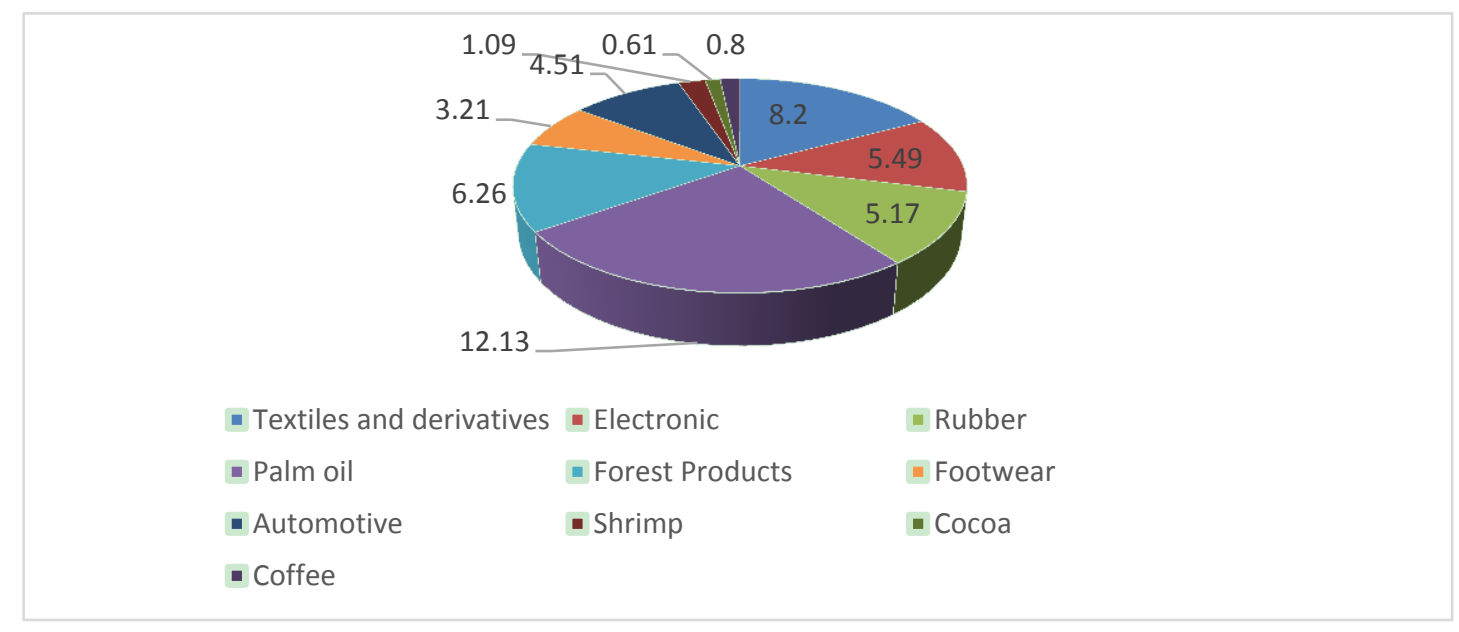

Figure 3. 10 Indonesia's major export commodities and their contribution to total non-oil and gas exports in 2017 Source: Ministry of Trade (2017)

Figure 3 showed that the 10 main export commodities contributed $47.48 \%$ to the total exports of Indonesia's non-oil and gas commodities. The contributions of each commodity are: Textiles and Textile Products (8.20\%); Electronics (5.49\%); Rubber (5.17\%); Palm (12.13\%); Forest Products (6.26\%); Footwear (3.21\%); Automotive (4.51\%); Shrimp (1.09\%); Cocoa $(0.61 \%)$; and Coffee $(0.80 \%)$. While the remaining $52.52 \%$ was contributed by other export commodities not included in the 10 main commodities.

Based on its production capacity, the potential for leading commodity offers can be demonstrated by the production capacity of these commodities in one year. Table 1 revealed data on the production capacity of Indonesia's superior products.

Table 1. Indonesia's most valuable exported products

\begin{tabular}{llll}
\hline Commodity & 2017 & 2018 & Changes for 2017-2018 (\%) \\
\hline Textiles and Textile Products & $1,005,375.0$ & $1,057,410.3$ & 5.18 \\
\hline Electronic & $110,469.8$ & $111,839.1$ & 1.24 \\
\hline Rubber & $3,376,884$ & $3,228,421$ & -4.40 \\
\hline Palm oil & $16,070,742,558$ & $15,461,902,070$ & -3.79 \\
\hline Forest Products & 12,931 & 60,805 & 370.23 \\
\hline Footwear & $155,658.0$ & $168,210.1$ & 8.06 \\
\hline Automotive & $395,995.4$ & $412,702.9$ & 4.22 \\
\hline Shrimp & $81,456.9$ & $92,640.0$ & 13.7 \\
\hline Cocoa & $12,073,356$ & $13,849,288$ & 14.71 \\
\hline Coffee & $280,536.9$ & $145,932.8$ & -47.98 \\
\hline
\end{tabular}

Source: BPS (2019) 
From the Table 1, it can be seen that in general the production of Indonesia's leading export commodities has increased from 2017-2018 although some have experienced a decline in production, such as rubber, palm, and coffee. Furthermore, commodities that are included in the 10 potential commodities include:

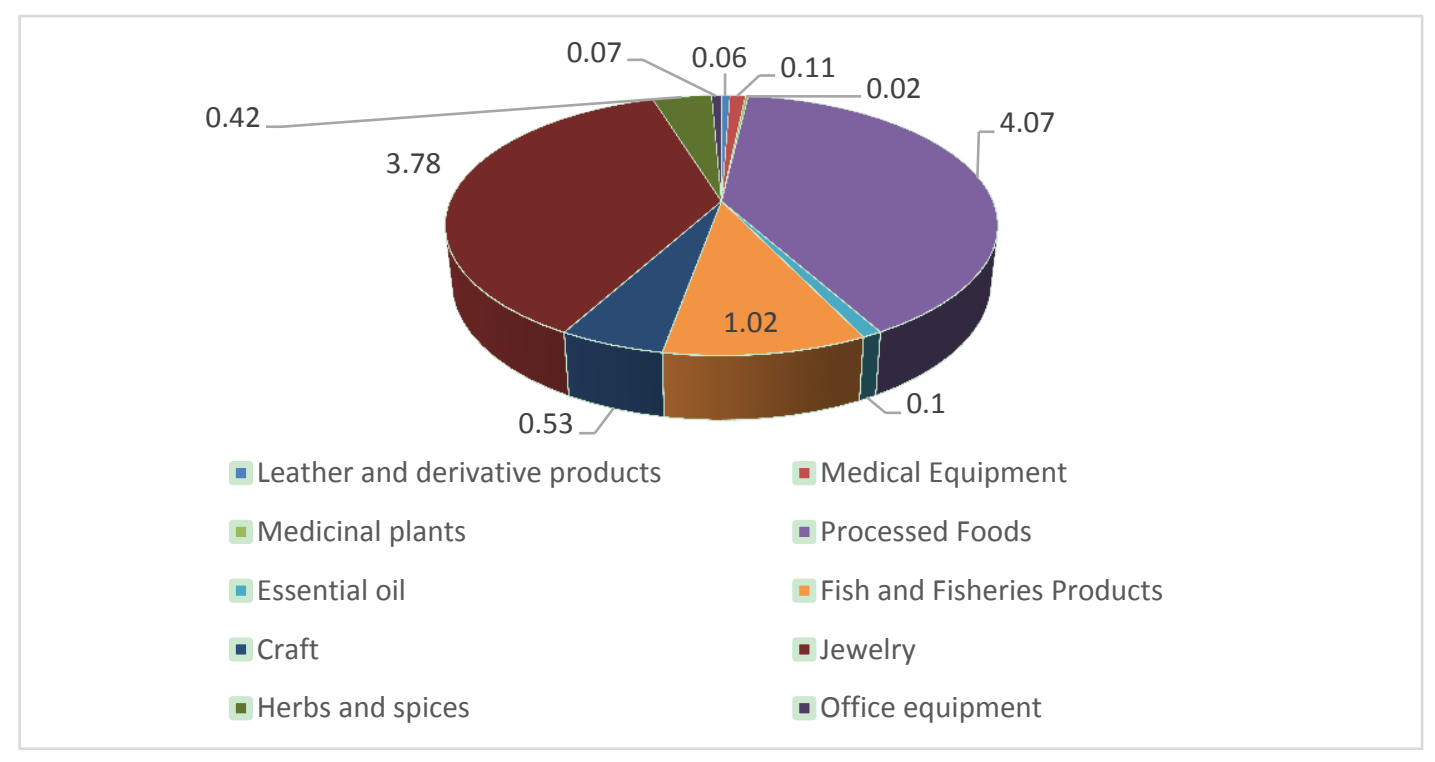

Figure 4. 10 Indonesia's potential export commodities and contribution to total non-oil and gas exports in 2017

Source: Ministry of Trade (2017)

Figure 4 shows that the contribution of 10 potential commodities amounted to $10.19 \%$ of Indonesia's total non-oil and gas exports in 2017. The contributions of each commodity are as follows: Leather and Leather Products (0.06\%); Medical Equipment (0.11\%); Medicinal Plants (0.02\%); Processed Foods (4.07\%); Essential Oils (0.10\%); Fish and Fisheries Products (1.02\%); Crafts (0.53\%); Jewelry (3.78\%); Spices (0.42\%); and Office Equipment (0.07\%). By knowing what commodities have the potential to be exchanged for trade returns, it is necessary to know countries that have the potential to become potential trade trade partners. From a group of leading and potential commodities, it is known that several major trading partner countries/export destination countries have the potential to become a defense equipment trade partner because of the good defense positions of these countries. Based on the Ministry of Trade's Trade Statistics data, Indonesia conducts international trade activities with more than 100 countries, but some of them have become major trading partners with high trade intensity and the value of exports produced. The following are some of the main export destination countries of Indonesia with the highest export value during 2018: 


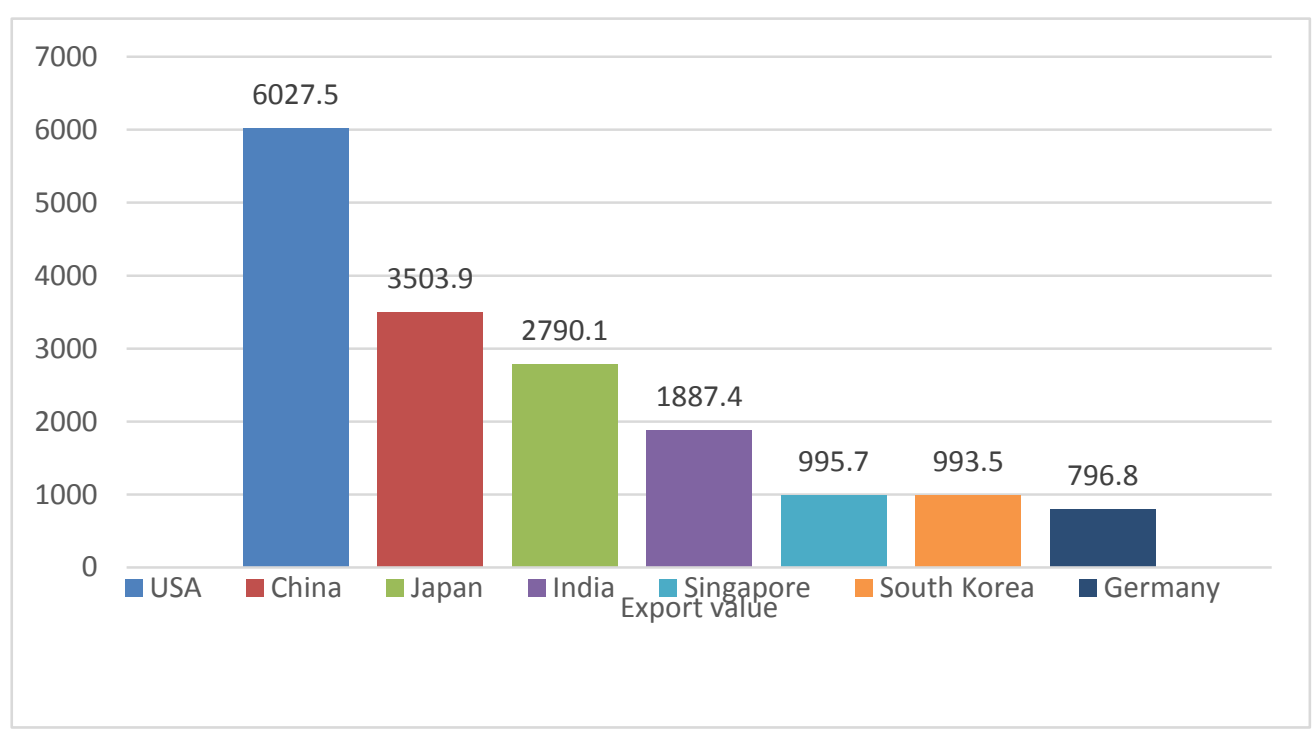

Figure 5. Main trading partners (exports) and export value produced in 2018

Source: Ministry of Trade, processed (2019)

Figure 5 showed that cumulatively in main commodities, exports to the United States generated foreign exchange of 6.027 billion US\$. In the second place is the China with an export value reaching 3.503 billion US\$ and in third place Japan with an export value of 2.790 billion US\$. Subsequent countries are India, Singapore, South Korea, and Germany with the export value generated respectively, 1.887 billion USD, 995.7 million US\$, 993.5 million US\$, and 796.8 million US\$. Due to the above countries are some of the main export destination countries of several leading and potential commodities from Indonesia, it can be said that the needs of some of their commodities are supplied/fulfilled by Indonesia. With this position, Indonesia has the opportunity to bring in the needs of defense equipment from these countries to produce mutually beneficial trade relations. If viewed from the defense positions of each country above, almost all countries occupy the top defense rankings in the world, for example the United States which is the main trading partner as well as the country with the first strongest military in the world.

According to The SIPRI Arms Industry Database (2017), defense companies from the United States hold the top rank among other companies in the world. The 1 st place is Lockheed Martin Corp. with total weapons sales in 2017 reaching 44,920 units. Furthermore, rank 2 and 3 are also occupied by companies from the United States, namely Boeing and Raytheon with weapons sales of 26,930 and 23,870 units respectively in 2017. Table 2 lists the top 10 defense companies in the world along with their countries of origin and weapons sales in 2016 and 2017.

Table 2. The largest defense company in the world and its arms sales data in 2016 and 2017

\begin{tabular}{llllll}
\hline \multicolumn{2}{l}{ Ratings } & \multirow{2}{*}{ Company } & Country of origin & \multicolumn{2}{l}{ Weapon Sales } \\
\cline { 1 - 2 } 2017 & 2016 & & & 2017 & 2016 \\
\hline 1 & 1 & Lockheed Martin Corp. & USA & 44920 & 40630 \\
\hline 2 & 2 & Boeing & USA & 26930 & 29510 \\
\hline 3 & 3 & Raytheon & USA & 23870 & 22910 \\
\hline 4 & 4 & BAE Systems & UK & 22940 & 22790 \\
\hline 5 & 5 & Northrop Grumman Corp. & USA & 22370 & 21400 \\
\hline 6 & 6 & General Dynamics Corp. & USA & 19460 & 19230 \\
\hline 7 & 7 & Airbus Group & Trans-Europe & 11290 & 12520 \\
\hline 8 & 9 & Thales & France & 9000 & 8170 \\
\hline 9 & 8 & Leonardo & Italy & 8860 & 8500 \\
\hline 10 & 13 & Almaz-Antey & Russia & 8570 & 6110 \\
\hline
\end{tabular}

Source: SIPRI (2017) 
From the list of companies in Table 2, it showed that most companies are originating from the United States, and has been recorded as the country of origin of several defense equipment used by Indonesia today. For example Lockheed Martin Corporation, Lockheed's Hercules (later merged to become Lockheed Martin) have been part of the Indonesian Air Force's fleet since 1960. At that time Indonesia bought 10 Hercules C-130 B planes in the form of 8 cargo aircraft and 2 tanker aircraft. Even Indonesia is the first country to use Hercules C-130 B aircraft outside the United States (Databoks.co.id, 2016). In early 2019, the Government of Indonesia through the Ministry of Defense will purchase C-130J Super Hercules transport aircraft from Lockheed Martin and Chinook transport helicopters from the United States. The purchase of heavy transport aircraft aims to support the architecture of defense development. Data on the arrival of Hercules aircraft to Indonesia from 1960-2016 is as follows:

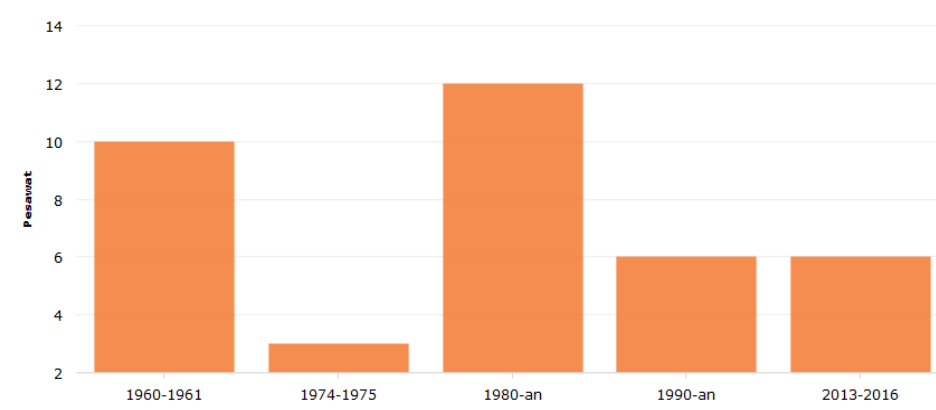

Figure 6. Arrival of Hercules aircraft to Indonesia 1960-2016

Source: Databoks.co.id (2016)

For Indonesia, it is important to know the defense conditions of the main trading partner countries because they also have the potential to become a trade defense equipment partner. According to Global Firepower (2019), the United States is the country ranked first in defense positions in the world, with 2,141,900 military personnel consisting of $1,281,900$ active personnel and 860,000 reserve personnel. In terms of army strength, the United States has 6,287 tanks ranked 3 out of 137 countries, 39,223 armored vehicles ranked 3, 992 artillery ranks 7, and 1,056 rocket launchers are ranked 6. In addition, the United States has 13,398 aircraft flies the most among 137 countries, including 2,362 fighter jets and 5,760 helicopters. While its maritime strength is supported by 415 warships. Furthermore, China ranks third in the position of defense in the world. China is supported by 2,693,000 military personnel consisting of 2,183,000 active personnel and 510,000 reserve personnel. China also has 3,187 combat aircraft units ranked 3 out of 137 countries, 13,050 tanks ranked 2 out of 137 countries, and 714 warships. India, Japan and South Korea also have defense levels above Indonesia, which are ranked 4, 6 and 7 respectively, so that they can become potential partners for Indonesia in the defense sector.

Germany as one of the main export destinations for Indonesian commodities also has a good defense position which is ranked 10th in the world with the number of military personnel 208,641 people. One of the German defense companies which has worked closely with Indonesia is Rheinmetall. This company already has a long history of producing pistols and artillery. The company is also advancing in the field of metal technology, so they are able to make high-tech military components and heavy weapons. In 2012, the Indonesian Government through the Ministry of Defense purchased 103 units of Leopard's main battle tank, 50 units of Marder 1A3 medium tanks, and 10 units of supporting tanks from Rheinmetall. In addition to the joint purchase of combat vehicles, Rheinmetall and PT Pindad began developing a large caliber ammunition factory in 2014, so that Leopard ammunition which has a $120 \mathrm{~mm}$ canon will be produced in Indonesia. In fact, PT Pindad was conceived to be the center of Leopard ammunition distribution throughout Asia. This is a strategic target in the procurement of Indonesian defense equipment, so that not only buying weapons, but also absorbing the system, so that the independence of the defense industry can support the ability of domestic defense.

\section{Conclusion}

Defense conditions can reflect the symbol of a country's strength in the international eye. To increase strength in the defense sector, one of them is done by procuring Defense and Security Equipment Tools as a supporting instrument. 
The trade return mechanism is a way to procure Defense and Security Equipment Tools from abroad. With trade returns, the country has the opportunity and the potential to further increase exports. In addition, in terms of budget, savings will also occur. Furthermore, domestic commodity sales will improve the national economy and people's welfare.

The results of this research show that positioning the defense strategic roles of potential trade partner countries, Indonesia can find out what defense equipment has the potential to be collaborated with these countries as well as making it a benchmark to improve Indonesia's defense ranking in the future. Externally , the trade return mechanism does not only involve two countries, it can be three or more, then internally in the country the process involves many parties such as several related Ministries, users, up to producers/industries of commercial commodities that will be involved in the trade process with defense equipment, so that the practice of trade returns brings economic opportunities, it is necessary to coordinate with a clear and integrated Standard Operating Procedure with each other. There are three important interrelated components that can bring economic opportunities, namely defense equipment expenditure, trade returns and the supply of trade-led commodities (military or general commodities). Furthermore, by mapping the leading and potential commodities as well as the main trading partner countries and their potential in the defense sector at the outset, an overview of potential trade returns can be carried out in the future. Thus, in the trade return planning process, commodities can be proposed that are suitable to the needs of trading partners. Long-term expectations, foreign exchange is no longer out for procurement of defense equipment because all of them can back up with commodities.

By mapping the potential of commodities owned by Indonesia, the government involved in the trade return process, particularly the Ministry of Trade and the relevant Ministries can prepare commodities in advance for exchange with defense equipment from abroad. In addition, the proposed commodity has been adjusted to the needs of partner countries, so that the commodity selection process can be carried out more quickly to reach an agreement. The next impact is the increase in income of domestic producers and the increase in foreign exchange earned from commodity exports.

This study has limitations, some of which are limited to studies that focus on Indonesian-Russian relations in the weapons purchase program. Furthermore, this study only focuses on a case of arms purchases in 2007. Further studies are expected to be able to analyze the countertrade mechanism in arms purchases with other partners, and facilitate the possibility of effective means of supplying weapons to developing countries. In addition, further studies are expected to be able to analyze longitudinally the effects of countertrade mechanism in arms purchases in various countries.

\section{Reference}

Arif, M., \& Kurniawan, Y. (2018). Strategic Culture and Indonesian Maritime Security. Asia \& the Pacific Policy Studies, 5(1), 77-89. https://doi.org/10.1002/app5.203

Basar, M. N. B., \& bt Zulkifli, N. (2019). The impact of GMA policy and naval modernisation towards indonesian maritime security. International Journal of Research in Social Sciences, 9(3), 125-138.

Bitzinger, R. A. (1994). The globalization of the arms industry: The next proliferation challenge. International Security, 19(2), 170-198. https://doi.org/10.2307/2539199

Bitzinger, R. A. (Ed.). (2009). The modern defense industry: political, economic, and technological issues: political, economic, and technological issues. ABC-CLIO.

Boediwardhana, W. (2014). Navy shows off latest warships, weapons. Jakarta Post, Wed, March 12, 2014. Retrieved from https://www.thejakartapost.com/news/2014/03/12/navy-shows-latest-warships-weapons.html

Brauer, J., \& Dunne, J. P. (2011). 13 Arms trade offsets: what do we know?. The handbook on the political economy of war (p. 243). https://doi.org/10.4337/9781849808323.00022

Bunn, M. E. (2007). Can deterrence be tailored?. Institute for National Strategic Studies, National Defense University.

Chowdhury, A. R. (1991). A causal analysis of defense spending and economic growth. Journal of Conflict Resolution, 35(1), 80-97. https://doi.org/10.1177/0022002791035001005

Databoks.co.id. (2016). Purchase and Grant of Air Force Hercules Aircraft. Retrieved from https://databoks.katadata.co.id/datapublish/2016/12/19/pembelian-dan-hibah-pesawat-hercules-milik-tni-angkat an-udara 
Deger, S. (1986). Economic development and defense expenditure. Economic Development and Cultural Change, 35(1), 179-196. https://doi.org/10.1086/451577

Dikici, E. (2015). Guns versus butter tradeoff: The theory of defense quality factor. Journal of Economics, Business and Management, 3(7), 704-709. https://doi.org/10.7763/JOEBM.2015.V3.270

Elden, S. (2006). Contingent sovereignty, territorial integrity and the sanctity of borders. SAIS Review of International Affairs, 26(1), 11-24. https://doi.org/10.1353/sais.2006.0008

Fletcher, R. (1996). Network Theory and Countertrade Transactions. International Business Review, 5(2), 167-189.

Gindarsah, I. (2016). Strategic hedging in Indonesia's defense diplomacy. Defense \& Security Analysis, 32(4), 336-353. https://doi.org/10.1080/14751798.2016.1233695

Goldstein, A. (2002). The political economy of high-tech industries in developing countries: aerospace in Brazil, Indonesia and South Africa. Cambridge Journal of Economics, 26(4), 521-538.

Gunawan, A. B. (2017). Civilian control and defense policy in Indonesia's nascent democracy. Reforming civil-military relations in new democracies (pp. 129-150). Springer, Cham.

Hennart, J. F., \& Anderson, E. (1993). Countertrade and the minimization of transaction costs: an empirical examination. JL Econ. \& Org., 9, 290.

Indonesian Ministry of Defense. (2018). National Defense Policy 2018. Wira Media, 70(54).

Indonesian Ministry of Trade. (2017, December). Indonesian Export Performance 2017. Warta Ekspor.

Jang, W. J., Kim, C. W., Kim, T. Y., \& Joung, T. Y. (2007). The Defense Offset Valuation Model. The DISAM Journal of International Security Assistance Management, 29(4), 91-101.

Joerding, W. (1986). Economic growth and defense spending: Granger causality. Journal of Development Economics, 21(1), 35-40. https://doi.org/10.1016/0304-3878(86)90037-4

Karim, S. (2014). Building Independence of the Indonesian Defense Industry (In Indonesian). Kepustakaan Populer Gramedia

Laksmana, E., \& Mattis, F. U. D. S. J. (2018, April). Are military assistance programs important for US-Indonesia ties?. East Asia Forum (Vol. 18).

Markusen, A. (2004). Arms trade as illiberal trade. Arms Trade and Economic Development: Theory, Policy, and Cases in Arms Trade Offsets (pp. 66-88). https://doi.org/10.4324/9780203392300_chapter_5

Ocampo, J. A. (2018). International asymmetries and the design of the International Financial System 1. Critical Issues in International Financial Reform (pp. 45-74). Routledge.

Puspita, A. (2018). Deliveries of Russian weapons to Indonesia (1960-2000). Master Thesis, Saint Petersburg State University.

Rahman, A. F., Anwar, S., \& Sumari, A. D. (2018). Analisis Minimum Essential Force (MEF) Dalam Rangka Pembangunan Cyber-Defense. Jurnal Pertahanan \& Bela Negara, 5(3).

Rangsimaporn, P. (2009). Russia's search for influence in Southeast Asia. Asian Survey, 49(5), 786-808.

Reisman, A., Fuh, D. C., \& Li, G. (1988). Achieving an advantage with countertrade. Industrial Marketing Management, 17(1), 55-63. https://doi.org/10.1016/0019-8501(88)90027-2

Sebastian, L. C., \& Gindarsah, I. (2013). Assessing military reform in Indonesia. Defense \& Security Analysis, 29(4), 293-307. https://doi.org/10.1080/14751798.2013.842709

Sjamsoeddin, S. (2016). Komitmen dan Perubahan: Suatu Persepsi dan Perspektif. KSPBooks.

Snyder, G. H. (2015). Deterrence and defense (Vol. 2168). Princeton University Press.

Stockholm International Peace Research Institute (SIPRI). (2017). The SIPRI Arms Industry Database. Retrieved from https://www.sipri.org/databases/armsindustry

Stockholm International Peace Research Institute (SIPRI). (2019). Global Firepower Index 2019. Retrieved from https://www.globalfirepower.com/countries-listing.asp

Till, G. (2015). Indonesia as a growing maritime power: possible implications for Australia. Sea Power Centre.

Tuwanto, P. (2015). Politik Pembangunan Industri Pertahanan Nasional di Era Global. Gema Keadilan, 2(1).

Weida, W. J., \& Gertcher, F. L. (2019). The political economy of national defense. Routledge. 